IZA DP No. 7463

How Do Stamp Duties Affect the Housing Market?

Ian Davidoff

Andrew Leigh

June 2013 


\title{
How Do Stamp Duties Affect the Housing Market?
}

\author{
Ian Davidoff \\ International Monetary Fund \\ Andrew Leigh \\ Australian National University \\ and IZA
}
Discussion Paper No. 7463
June 2013

IZA
P.O. Box 7240
53072 Bonn
Germany

Phone: +49-228-3894-0
Fax: +49-228-3894-180
E-mail: iza@iza.org

Any opinions expressed here are those of the author(s) and not those of IZA. Research published in this series may include views on policy, but the institute itself takes no institutional policy positions. The IZA research network is committed to the IZA Guiding Principles of Research Integrity.

The Institute for the Study of Labor (IZA) in Bonn is a local and virtual international research center and a place of communication between science, politics and business. IZA is an independent nonprofit organization supported by Deutsche Post Foundation. The center is associated with the University of Bonn and offers a stimulating research environment through its international network, workshops and conferences, data service, project support, research visits and doctoral program. IZA engages in (i) original and internationally competitive research in all fields of labor economics, (ii) development of policy concepts, and (iii) dissemination of research results and concepts to the interested public.

IZA Discussion Papers often represent preliminary work and are circulated to encourage discussion. Citation of such a paper should account for its provisional character. A revised version may be available directly from the author. 


\section{ABSTRACT}

\section{How Do Stamp Duties Affect the Housing Market?*}

Land transfer taxes are a substantial portion of the cost of moving house in many developed countries. Since stamp duties are endogenous with respect to the house price, we create an instrumental variable that is the stamp duty on a property, given that postcode's starting house price and the national house price trend. In a specification with postcode and year fixed effects, this instrument effectively captures policy changes and nonlinearities in the stamp duty schedule. We find that the impact of an increase in the tax rate is to lower house prices, suggesting that the economic incidence of the tax falls on the seller. We also observe impacts of stamp duty on housing turnover. A 10 per cent increase in stamp duty lowers turnover by 3 per cent in the first year, and by 6 per cent if sustained over a 3 year period.

JEL Classification: $\quad H 22, H 24, H 71, R 21, R 23$, R28

Keywords: $\quad$ tax incidence, land sales taxation, residential mobility

Corresponding author:

Andrew Leigh

Unit 8/1 Torrens St

Braddon ACT 2612

Australia

E-mail: andrew_leigh@ksg02.harvard.edu

\footnotetext{
* We are grateful to Daniel Carr and seminar participants at the National Tax Association's 2008 meetings in Philadelphia and RMIT University for valuable comments on earlier drafts. This paper does not represent the views of the IMF.
} 


\section{Introduction}

A key insight of public economics has been to demonstrate that the economic incidence of a tax can differ from its statutory incidence. Put another way, the person who ends up paying a tax may not be the person upon whom the tax is levied. Studies of tax incidence have variously shown that payroll taxes are mostly borne by workers, that retail sales taxes are mostly borne by consumers, and that corporate taxes are borne by consumers, workers, and investors.

Over recent decades, developed countries have made increasing use of land transfer taxes, also known as stamp duties. ${ }^{1}$ As an immobile factor of production, land has the potential to be an efficient tax base. From an administrative standpoint, stamp duties are typically levied on the buyer (i.e. the statutory incidence of the tax is on the purchaser). But is the economic incidence of stamp duty entirely on the buyer, entirely on the seller, or shared between both parties? And what impact do land transfer taxes have on housing turnover? The answers to these questions bear on whether or not stamp duties limit residential mobility (and therefore labour mobility) and lead to misallocation of the housing stock.

From a theoretical perspective, inelastic factors bear the economic burden of taxes. Thus if buyers are more price-inelastic than sellers, then buyers will bear most of the tax burden (and house prices will not change much in response to a change in house sales taxes). Conversely, if sellers are more price-inelastic than buyers, then sellers will bear most of the tax burden (and house prices will fall by most of the value of a change in house sales taxes). Regardless of incidence, theory also predicts that higher taxes will increase the 'tax wedge' between buyers and sellers, and reduce total sales.

In this paper, we investigate the impact of stamp duties, using data from Australia, a jurisdiction where stamp duty averages around 3 per cent of the property value. We

\footnotetext{
${ }^{1}$ Stamp duties on land transactions differ from recurrent land and property taxes. Where land and property taxes typically refer to recurrent taxes levied on the unimproved value of land by local governments, stamp duties (which in Australia are levied by state and territory governments) only apply when real property is transferred from own owner to another. Reflecting the one-off, point in time nature of stamp duties, the state revenues raised from this tax, though substantial, can also be volatile (Australian Government, 2010).
} 
exploit a rich dataset containing the full universe of housing sales over a 13-year period, which happens to be one of the periods of most rapid increase in Australian property values. An advantage of using Australian data is that service delivery is largely homogenous across jurisdictions, due to federal formulas that equate funding across states and territories. This reduces the probability that changes in tax rates are correlated with changes in the quality of service delivery.

To preview our results, we find that stamp duties reduce house prices and turnover rates. The effect of stamp duties on prices tends to be larger close to state boundaries, where there is more competition from the neighbouring jurisdiction. The price impacts imply that the incidence of stamp duty is on the seller.

\section{Background and Previous Literature}

From an international perspective, house prices in Australia have been relatively high for almost two decades (IMF 2012, The Economist 2012). There is general agreement that house price inflation in the mid-1990s was driven by deregulation of the financial sector, which facilitated unprecedented demand for housing (see, for example Ellis 2006). Following this period, house prices continued to grow rapidly for over a decade, only flattening out with the onset of the Global Financial Crisis in 2007.

The causes of this ongoing growth have been the subject of extensive analysis and debate, reflecting the complex task of explaining house price movements (see Yates, 2011 for an overview of this literature). Some studies have suggested that price expectations drove continuing demand (see for example Hatzvi and Otto, 2008), while others argue that demand was driven by increases in household wealth and consumption (Yates and Whelan, 2009).

Supply side factors have also been a significant contributing factor. Over the period in question, supply of housing in Australia has remained relatively static. For example, the number of homes completed in Australia was constant at around 100,000 per year throughout the 1990s and 2000s (ABS 2012a), despite the population increasing by nearly one-third during that period. A potential explanation of this is the 
high opportunity cost associated with housing construction in the face of a historic mining boom characterised by record terms of trade and unprecedented infrastructure investment. A range of direct cost drivers have also been pinpointed as factors contributing to supply pressures, including lengthy planning approval processes (leading to increases in financial holding costs), restrictive land release policies (leading to higher land cost) and infrastructure charges and taxes, including stamp duties (NHSPC 2011)

Empirical studies of the incidence of development impact taxes have found that such taxes are typically borne by homebuyers (see for example Huffman et al, 1988; Brueckner, 1997). A separate body of work has looked at the impact of recurrent property taxes on house prices and found that they are generally capitalized into lower house prices (see for example Oates, 1969; Palmon and Smith, 1998). At the same time, a number of studies have shown that the imposition of general transaction costs (a defining feature of stamp duties as compared to recurrent land taxes) have a significant negative impact on labour mobility (see Van Ommeren 2008 for a comprehensive overview). For example, Van Ommeren and Leuvensteijn (2005) used a risk hazard model of moving to a rented or owned property to infer that a 1 per cent increase in the value of transaction costs - measured as percentage of the value of an owned residence - decreased residential mobility by 8 per cent. Modelling the impact of stamp duty, Lundborg and Skedinger (1999) add transaction costs into a search model of the housing market, with the result that higher stamp duties lower the returns from search, which in turn reduces search intensity, sales rates and house prices

Kopczuk and Munroe (2012) found that a so-called 'mansion tax' - a transaction tax of one per cent applied to the sale of properties in New York State worth more than \$1 million- fell on sellers, with the price impact exceeding 100 per cent of the value of the tax. Hilber and Lyytikainen (2012) similarly exploited a discontinuity (or 'kink') in the application of a real estate transfer tax in the UK to assess the impact of the tax on mobility. By comparing the behavior of households who own property on either side of a cut-off point where the tax jumped sharply, they found that an increase in the tax equivalent to approximately 1.5 per cent of property prices reduced the chances of moving house by 30 per cent. Finally, using a border-discontinuity 
approach to exploit the introduction of a (unexpected) real estate transfer tax in Toronto, Canada, Dachis et al (2012), showed that the 1.1 per cent tax reduced sales (turnover) of homes by 15 per cent. The study also found that the tax was capitalized into the house prices at a rate equal to the tax.

\section{Data and Empirical Specification}

The data used in this study were purchased from Australian Property Monitors (APM), which is Australia's leading firm that compiles house price data. APM obtains data from state and territory Valuer-General's offices, which is then cleaned by supplementing it with information from real estate agents (via an arrangement that APM has with the Real Estate Institute). The cleaning process is necessary because the data from the Valuer-General's offices sometimes has non-credible sales figures (e.g., sales that are an order of magnitude higher or lower than other recent sales in the same street), or is incomplete in some important detail (e.g., missing a street number). In many cases, errors in the Valuer-General's database can be corrected by reference to data held by real estate agents. ${ }^{2}$ Following the cleaning process, APM estimates that their database covers more than 95 per cent of all house sales. ${ }^{3}$

Since APM do not sell their full database, this analysis is based upon postcode-level means rather than data for individual sales. ${ }^{4}$ Consequently, we are unable to control for changes in quality from one year to the next. To help address this concern, we exclude sales of units (condominiums) from the dataset, since units are likely to be more heterogeneous (within a given postcode) than houses. Units comprise only about one-fifth of the sales in the sample frame (about 1 million of the 5 million sales that underlie the dataset).

\footnotetext{
${ }^{2}$ For example, if a sale was listed as $\$ 35,000$ by the Valuer-General and the real estate agent database states that the last asking price was \$370,000, APM might assume that the correct sale price was $\$ 350,000$.

3 The source of this information is email and telephone conversations with Eva Knight, APM's Head of Research and Analytics during the period when we purchased the data.

${ }^{4}$ A small number of postcodes overlap state borders. In these cases, we have separate data for sales on either side of the border, and we treat them as separate units of observation. Formally, the analysis is based upon postcode $\times$ state observations, but for expositional simplicity we refer to these as postcodes.
} 
The coverage of the APM dataset varies across Australia's eight states and territories, being 1993-2005 for the Australian Capital Territory (ACT), New South Wales (NSW), Queensland (Qld), South Australia (SA), and Western Australia (WA); 19952005 for Victoria (Vic); 1998-2005 for the Northern Territory (NT); and 2003-2005 for Tasmania (Tas). For all states, the dataset covers house sales that had been registered by the end of 2006, which allows for up to a 12-month lag in the official registration. ${ }^{5}$

The key price variable is the mean of the log house prices in a postcode (also known as the log of the geometric mean). This measure is preferable to the arithmetic mean, which is sensitive to changes in the prices of the most expensive houses. It is also preferable to the median house price, which is unaffected by changes that only impact the tails of the distribution. A simple way to think about the geometric mean is that if the cheapest house in a postcode increases in value by 10 per cent, this has approximately the same impact on the geometric mean as if the most expensive house in a postcode increases in value by 10 per cent.

The other main measure of the housing market that we use is the log of the number of sales in a postcode in a given year. This excludes postcodes in which no houses were sold, which comprise 4 per cent of the postcodes in the sample.

For some of the specifications, we exploit the distance to the state boundary (as a way of testing whether the effect of tax competition increases nearer to postcodes with different tax regimes). Distances were calculated using a dataset purchased from FindMap Pty Ltd, which contains the distance between the centroids of all possible pairs of postcodes in Australia. For each postcode, we calculate the shortest distance to a postcode in another state, and assign this as the distance from the state border.

\footnotetext{
${ }^{5}$ We drop two postcode-year observations for the Northern Territory, which appear to be dominated by the sale of extremely large cattle stations (postcode 872 in 2002, where a single property sold for \$5 million; and postcode 862 in 2004, where two properties sold with a geometric mean of \$29 million). The next-highest set of prices is for central Sydney and Melbourne, with much larger numbers of sales per postcode.
} 
Data on tax rates were obtained from legal archives. ${ }^{6}$ Where the tax schedule changes part-way through the calendar year, we pro-rata the two rates. For example, if rates change at the end of April, we assign a tax rate to that year which is $1 / 3^{\text {rd }}$ the rate prevailing from January to April, and $2 / 3^{\text {rds }}$ the rate prevailing from May to December.

By way of example, Table 1 sets out the stamp duty schedule that prevailed in NSW during the years covered by our study. This shows a steeply progressive stamp duty schedule, with marginal stamp duty rates rising from 1.25 per cent for the first $\$ 14,000$ of property value to 7 per cent for the amount by which the property value exceeds \$3 million. With the exception of a new stamp duty rate applying to houses worth \$3 million or more (introduced in 2004), the NSW stamp duty rates and brackets were not adjusted throughout the period that we study. This meant that the average stamp duty rate on a NSW house sale rose from 2.4 per cent in 1994 to 3.1 per cent in 2005.

Table 1: Sample Stamp Duty Schedule (New South Wales)

Property Sale Price

$\$ 0-\$ 14,000$

$\$ 14,001-\$ 30,000$

$\$ 30,001-\$ 80,000$

$\$ 80,001-\$ 300,000$

$\$ 300,001$ - \$1,000,000

$\$ 1,000,001-\$ 3,000,000$

$\$ 3,000,001$ and above*
Marginal Stamp Duty Rate

$1.25 \%$

$1.5 \%$

$1.75 \%$

$3.5 \%$

$4.5 \%$

$5.5 \%$

$7 \%$

* The top stamp duty bracket was introduced in 2004.

\footnotetext{
${ }^{6}$ Some states and territories provided stamp duty concessions to first home buyers. We have had difficulty compiling a comprehensive database of such concessions, but modelling them would in any case be difficult due to shifts in the proportion of homebuyers who were eligible for concessions. The effect of omitting this aspect of the policy is likely to be to attenuate our estimates towards zero.
} 
According to official taxation statistics (ABS 1995, 2012b), revenue from land stamp duty increased from 15 per cent of state government revenue in 1993-94 to 24 per cent of state government revenue in 2005-06 (as a share of total federal, state and local government revenue, stamp duty on land rose from 3 to 4 per cent over this period). This suggests that stamp duty comprises a considerably larger share of revenue for Australian states than for most US states and cities. ${ }^{7}$

A key empirical challenge in estimating the relationship between taxes and prices is that there is a mechanical relationship between the stamp duty paid on a property and the sale price. Therefore, if one were to simply regress the sale price on the tax payable on that property, the coefficient would capture both the mechanical fact that the tax amount is a function of the price, as well as any behavioural impact of taxes on prices. (Similar issues arise in estimating the impact of income taxes on wages: see e.g. Feldstein and Wrobel 1998; Leigh 2008.)

To address this problem, we form an instrumental variable that is the stamp duty on an average property in that postcode, assuming that prices in that postcode took the same ratio in the first available year, and rose with the national trend. For example, if sales data are available for 1993-2005, the instrumented stamp duty amount in 2002 is based on the national price in 2002, multiplied by the average price in that postcode in 1993, divided by the average national price in 1993. More specifically, if a postcode had average house prices in 1993 that were 80 per cent of the national price, then our approach would assign that postcode a house price that was 80 per cent of the national price in all years. This price would then be applied to the stamp duty schedule prevailing in that state and year to determine the instrumented stamp duty amount.

Given that all our specifications include postcode fixed effects (which remove the initial price ratio) and year fixed effects (which remove the national price changes), the instrumental variable is effectively identified from within-state policy changes and the non-linear nature of the stamp duty schedule. To avoid potential problems caused by regression towards the mean, we also take the added precaution of dropping the

\footnotetext{
${ }^{7}$ Dachis et al (2012) notes that stamp duty comprises 3 per cent of revenue for New Hampshire and Florida, 4 per cent for District of Columbia, and 5 per cent for New York.
} 
first year's data for each postcode (in the example just given, this would mean dropping data from 1993.) Alternative approaches, such as keeping the first year's data, or forming a ratio based on all years for which sales data are available, produce similar results (see Tables A1 to A4).

To provide some intuition for this approach, Figure 1 plots data for the four postcodes with the highest turnover rates in 1994. The solid line shows actual house prices (the geometric mean), while the dashed line shows predicted house prices, assuming that prices had followed the same national trend. By construction, the two series start at a similar point (though not exactly the same point, because our preferred approach drops the first year's data). Note that the dashed line has the same slope across all four postcodes, since it reflects the rate at which the average national price increased over the period 1994-2005. In contrast, the solid line, which depicts actual price growth, follows a slightly different trajectory in each postcode.

\section{Figure 1: Actual and predicted house prices for the 4 postcodes with the highest turnover}
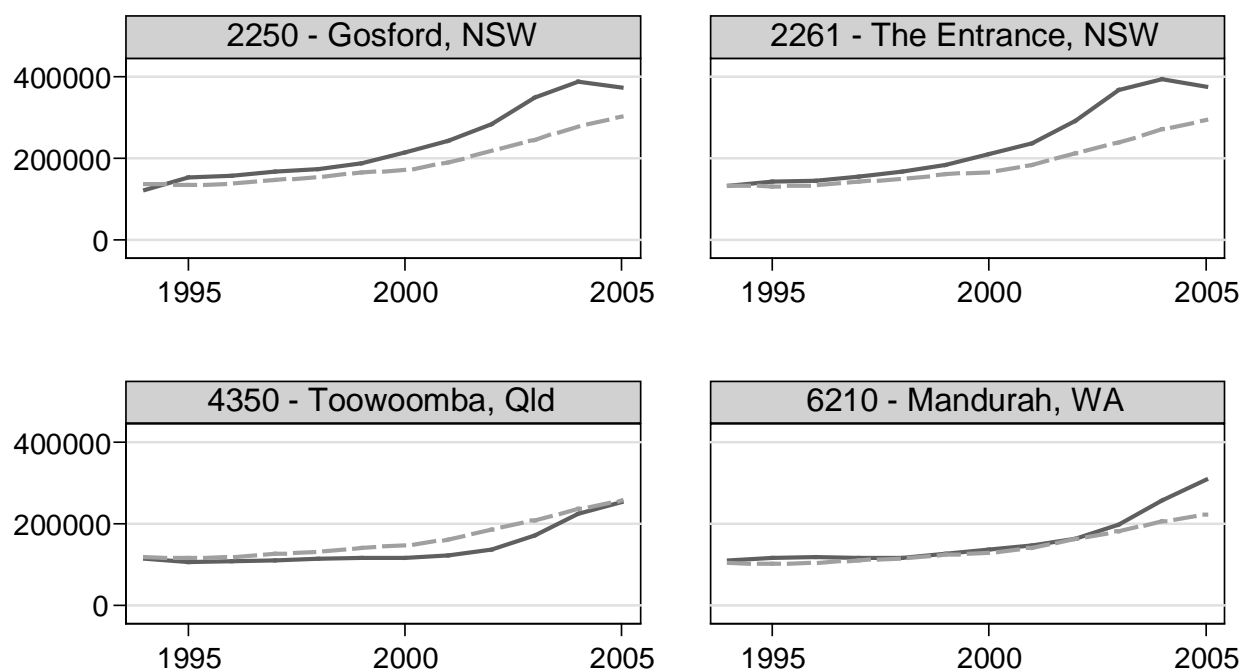

Actual price

----- Predicted price

In Figure 2, we calculate the weighted mean tax rate for each state and territory (using both actual and predicted prices). The two series track each other quite closely. All states increase their average tax rates over the period for which data are available, with the largest increases being in the ACT, Vic and WA. 


\section{Figure 2: Actual and predicted land turnover taxes by state}
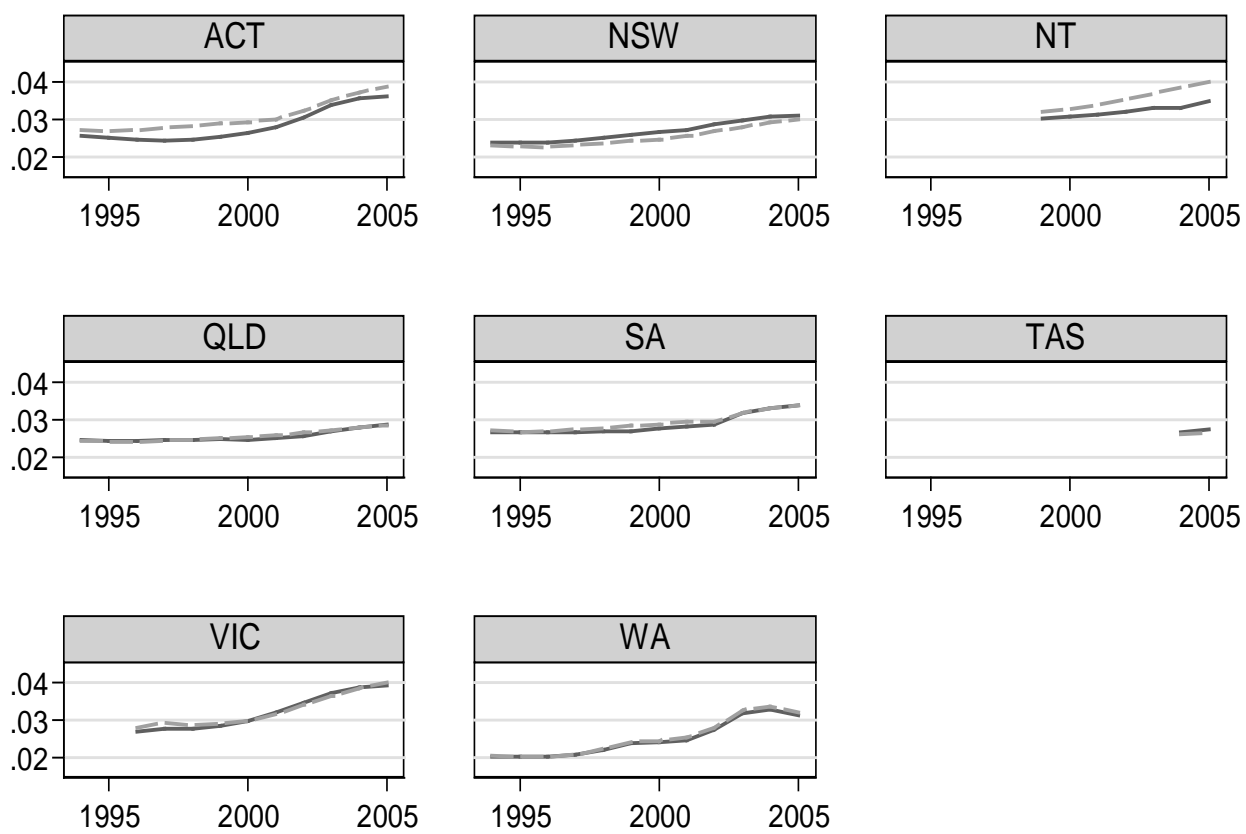

\section{Actual tax rate ------ Predicted tax rate}

Formally, using data on geometric mean sale prices and turnover in postcode $i$ in year $t$, we calculate two stamp duty amounts. The first is $\tau$, which is the actual tax bill based on the geometric mean sale price. The second amount is $T$, which is the predicted tax bill, assuming that prices in that postcode took the same ratio in the first available year, and rose with the national trend.

In the first stage, we regress the actual tax bill on the predicted tax bill, with postcode and year fixed effects. In the second stage, we use the fitted values to test the impact of tax changes on $Y$, which is either the log of the geometric mean house price, or the $\log$ of the number of houses sold. $\varphi$ and $\beta$ are parameters.

$$
\begin{aligned}
& \ln (\tau)_{i t}=\varphi \ln (T)_{i t}+I_{i}^{\text {Postcodes }}+I_{t}^{\text {Years }}+\mu_{i t} \\
& \ln (Y)_{i t}=\beta \ln (\hat{\tau})_{i t}+I_{i}^{\text {Postcodes }}+I_{t}^{\text {Years }}+\varepsilon_{i t}
\end{aligned}
$$


Standard errors are clustered at the postcode level, to account for possible serial correlation within postcodes over time (Bertrand, Duflo and Mullainathan 2004). ${ }^{8}$ In specifications where the dependent variable is the log of the house price, observations are weighted by the number of sales. ${ }^{9}$ Where the dependent variable is the log of the number of sales, the regressions are unweighted.

We also carry out various robustness checks. We estimate the impact of taxes in the region close to the state border. This allows for the possibility that the behavioural effect of taxes might be larger for individuals who can more readily purchase a house in another jurisdiction. We also explore the impact of lagged tax rates, which accounts for the possibility that the housing market may take some time to adjust to a change in tax rates. Additionally, we estimate specifications with state×year fixed effects, and with an instrument based on state time trends in house prices (rather than national trends).

\section{Results}

Table 2 shows the relationship between stamp duty and house prices. In the first column, we present results using an IV specification (instrumenting $\ln (\tau)$ with $\ln (T)$ ), while in column 2, we estimate a reduced-form regression (using $\ln (T)$ directly). In the IV specification, the first stage result is very strong, with an F-statistic on the excluded instrument of 194 (well above the 10 that Staiger and Stock 1997 suggest as a rule of thumb), and a partial R-squared of 0.08. The p-value on a Kleibergen-Paap LM test is less than 0.001 , providing reassurance that the equation is not underidentified.

\footnotetext{
${ }^{8}$ Results are estimated using Stata's xtivreg2 command (Schaffer 2007), which allows clustering, and does not require weights to be constant within panels.

${ }^{9}$ The coefficient is similar in unweighted specifications. The coefficient on the log stamp duty variable in this specification is -0.275 ( $\mathrm{SE}=0.087$ ) in the IV specification using all postcodes, and -0.159 ( $\mathrm{SE}=0.037$ ) in a reduced-form specification using all postcodes). Our preferred specification is the weighted one, since it more closely approximates what the results would be if the regression were run using individual sale data.
} 
In column 1 of Table 2, we estimate that the elasticity of house prices with respect to stamp duty is -0.26 , suggesting that a 10 per cent rise in stamp duty leads to a $2 \frac{1}{2}$ per cent fall in house prices. In the reduced-form specification, the coefficient is only slightly smaller (-0.20). The difference between the IV and reduced-form specifications is a measure of the size of the coefficient on $\ln (T)$ in the first-stage of the IV regression. If that coefficient is 1, then the reduced form and IV specifications will produce the same elasticity. If the coefficient on the excluded instrument in the first-stage IV regression is greater than 1, then it will act to 'scale down' the IV elasticity, relative to the reduced-form specification. Conversely, if the coefficient on the excluded instrument in the first-stage IV regression is smaller than 1 , then it will act to 'scale up' the IV elasticity, relative to the reduced-form specification. In this case, the coefficient on $\ln (T)$ in the first-stage of the IV regression is 0.77 ( $\mathrm{SE}=0.06$ ), which effectively 'scales up' the reduced-form coefficient from -0.20 to -0.26 . The more closely that the values of the instrumented stamp duty and the actual stamp duty track one another, the closer the IV and reduced-form specifications will be. Although the reduced-form model is more efficient, we prefer the IV specification on the grounds that it is consistent (a Hausman test rejects equality of the stamp duty coefficient in these two specifications).

In column 3, we re-estimate the regressions, but this time restricting the sample to postcodes less than 50 kilometres from the nearest state border. The notion underlying this cut-off is that such a distance represents a plausible commuting zone, potentially allowing individuals to move to a different state without changing their job. (Because the regressions are weighted by turnover, this specification is dominated by conurbations that span borders: such as Tweed-Coolangatta, Albury-Wodonga and Queanbeyan-Canberra.) We find that the elasticity of house prices with respect to stamp duty rates is substantially higher in these regions.

However, although the elasticity in column 3 of Table 2 is around -1.2, it is possible that the IV results are higher towards the state border because the first-stage is less precisely estimated. Measurement error in either $\ln (\tau)$ or $\ln (T)$ will affect the coefficient on the excluded instrument in the first-stage regression. Indeed, in the full sample, the coefficient on the predicted stamp duty rate in the first stage is 0.77 
( $\mathrm{SE}=0.06$ ); while in the bordering postcodes sample, the coefficient on the predicted stamp duty rate in the first stage is $0.40(\mathrm{SE}=0.12)$.

Nonetheless, the larger elasticity in bordering postcodes does not appear to be solely due to differences in the first-stage regression. Even in a reduced-form specification, the elasticity in the bordering postcodes sample (column 4) is 0.46: nearly twice as large as the elasticity in the reduced-form specification with all postcodes (column 2). Because of the effect of the small sample size on the precision of our IV estimator, we are inclined to prefer the reduced form specification when looking at bordering postcodes. We therefore estimate that a 10 per cent increase in stamp duty lowers house prices in bordering postcodes by 4-5 per cent.

\begin{tabular}{lcccc}
\hline \multicolumn{2}{l}{$\begin{array}{l}\text { Table 2: Stamp Duty and House Prices } \\
\text { Dependent variable is the mean log house price }\end{array}$} & & \\
\hline & {$[1]$} & {$[2]$} & {$[3]$} & {$[4]$} \\
& $\begin{array}{c}\text { Full sample } \\
\text { (IV) }\end{array}$ & $\begin{array}{c}\text { Full sample } \\
\text { (reduced } \\
\text { form) }\end{array}$ & $\begin{array}{c}<50 \mathrm{~km} \text { from } \\
\text { border (IV) }\end{array}$ & $\begin{array}{c}<50 \mathrm{~km} \text { from } \\
\text { border } \\
\text { (reduced } \\
\text { form) }\end{array}$ \\
& & & & $-0.459^{* * *}$ \\
Log (stamp duty) & $-0.255^{* * *}$ & $-0.196^{* * *}$ & $-1.16^{* *}$ & {$[0.091]$} \\
Postcode fixed & {$[0.073]$} & {$[0.042]$} & {$[0.577]$} & Yes \\
effects & Yes & Yes & Yes & \\
Year fixed effects & Yes & Yes & Yes & Yes \\
Observations & 25111 & 25111 & 3360 & 3360 \\
Postcodes & 2469 & 2469 & 327 & 327 \\
R-squared & 0.81 & 0.89 & 0.43 & 0.91 \\
\hline
\end{tabular}

Note: ***, ** and * denote statistical significance at the 1\%, 5\% and 10\% levels, respectively. Standard errors, clustered at the postcode level, in brackets. In the IV specifications, R-squared is the uncentered $\mathrm{R}$-squared in the second-stage regression. In columns 1 and 3, the $\log$ of the actual stamp duty $(\ln (\tau))$, is instrumented using the stamp duty on an average property in that postcode, assuming prices rose with the national trend $(\ln (T)$ ). In columns 2 and 4, we directly use $\ln (T)$ as the stamp duty measure. All specifications are weighted by the number of house sales in that postcode-year cell.

How do changes in stamp duty affect the number of houses sold in a postcode? In Table 3, we estimate models using the log of the number of sales as the dependent variable. In the full sample, instrumenting the actual stamp duty with the predicted stamp duty (column 1), we find an elasticity of -0.32, which implies that a 10 per cent increase in stamp duty lowers housing turnover by 3 per cent (this is our preferred specification). In the reduced-form specification (column 2), the elasticity is slightly 
lower, at -0.19 . When we restrict the sample to sales near state borders (columns 3 and 4 of Table 3), the effects are not statistically significant (the point estimates fall slightly and the standard errors increase considerably). While we would ordinarily expect the price effects and turnover effects to move in the same direction, the standard errors in Table 3 do not allow us to rule out the possibility that the impact on turnover is the same near state borders as in the full sample.

\begin{tabular}{|c|c|c|c|c|}
\hline \multicolumn{5}{|c|}{$\begin{array}{l}\text { Table 3: Stamp Duty and House Sales } \\
\text { Dependent variable is the log of the number of house sales }\end{array}$} \\
\hline \multirow{4}{*}{ Log (stamp duty) } & {$[1]$} & {$[2]$} & {$[3]$} & {$[4]$} \\
\hline & $\begin{array}{l}\text { Full sample } \\
\text { (IV) }\end{array}$ & $\begin{array}{l}\text { Full sample } \\
\text { (reduced } \\
\text { form) }\end{array}$ & $\begin{array}{l}<50 k m \text { from } \\
\text { border (IV) }\end{array}$ & $\begin{array}{l}<50 \mathrm{~km} \text { from } \\
\text { border } \\
\text { (reduced } \\
\text { form) }\end{array}$ \\
\hline & $-0.322 * * *$ & $-0.186 * * *$ & -0.216 & -0.070 \\
\hline & [0.119] & {$[0.067]$} & [0.627] & [0.202] \\
\hline $\begin{array}{l}\text { Postcode fixed } \\
\text { effects }\end{array}$ & Yes & Yes & Yes & Yes \\
\hline Year fixed effects & Yes & Yes & Yes & Yes \\
\hline Observations & 25111 & 25111 & 3360 & 3360 \\
\hline Postcodes & 2469 & 2469 & 327 & 327 \\
\hline R-squared & 0.10 & 0.12 & 0.10 & 0.12 \\
\hline
\end{tabular}

Note: ***,** and * denote statistical significance at the 1\%, 5\% and 10\% levels, respectively. Standard errors, clustered at the postcode level, in brackets. In the IV specifications, R-squared is the uncentered R-squared in the second-stage regression. In columns 1 and 3, the log of the actual stamp duty $(\ln (\tau))$, is instrumented using the stamp duty on an average property in that postcode, assuming prices rose with the national trend $(\ln (T))$. In columns 2 and 4, we directly use $\ln (T)$ as the stamp duty measure.

Until this point, we have assumed that the effect of stamp duty on house values and turnover occurs in the same year. But it is possible that the effects may take time to manifest themselves. This could occur due to information lags (if buyers and sellers do not immediately realise that stamp duty rates have risen), or in cases where property sale negotiations take place across two calendar years.

In Table 4, we re-estimate the house price models, but with additional lags (one additional year in Panel A, two additional years in Panel B). For each regression, we show the coefficients for each year, plus the sum of the three coefficients, which denotes the impact on prices of a stamp duty rise that persists over 2 years (Panel A) or over 3 years (Panel B). 
In the full sample, the summed coefficients are slightly larger than the corresponding estimates from Table 2. The elasticity over a 2 year period (columns 1 and 2 of Panel A) is -0.22 in the IV specification and -0.27 in the reduced form specification. Over a 3 year period, the elasticity in the full sample (columns 1 and 2 of Panel B) is -0.15 in the IV specification and -0.37 in the reduced form specification. In general, the summed coefficients are smaller in the IV specification, but larger in the reduced form specification.

The specification that only includes postcodes near state borders is presented in columns 3 and 4 of Table 4 . In the IV specification (column 3), neither summed elasticity is significant, most likely because the small sample size leads to an imprecisely estimated first stage regression. Again, we prefer the reduced form results for bordering postcodes. In the reduced form specification (column 4), the 2-year elasticity is -0.63 , while the 3 -year elasticity is -0.66 . These are both larger than the 1 year elasticity, which is -0.46 (Table 2, column 4). In common with the reduced form results for the full sample, these results suggest that the impact of stamp duty on prices is slightly larger when sustained over a 2 or 3 year period. 


\begin{tabular}{|c|c|c|c|c|}
\hline \multicolumn{5}{|c|}{ Table 4: Stamp Duty and House Prices (Medium Run) } \\
\hline \multicolumn{5}{|c|}{ Dependent variable is the mean log house price } \\
\hline & [1] & [2] & [3] & [4] \\
\hline & $\begin{array}{l}\text { Full sample } \\
\text { (IV) }\end{array}$ & $\begin{array}{l}\text { Full sample } \\
\text { (reduced } \\
\text { form) }\end{array}$ & $\begin{array}{l}<50 \mathrm{~km} \text { from } \\
\text { border (IV) }\end{array}$ & $\begin{array}{l}<50 \mathrm{~km} \text { from } \\
\text { border } \\
\text { (reduced } \\
\text { form) }\end{array}$ \\
\hline \multicolumn{5}{|c|}{ Panel A: Two-year impacts } \\
\hline \multirow[t]{2}{*}{ Log (stamp duty) } & $0 . \overline{432}$ & -0.106 & 3.182 & 0.028 \\
\hline & {$[0.307]$} & {$[0.071]$} & {$[2.190]$} & {$[0.185]$} \\
\hline \multirow[t]{2}{*}{$\log (\text { stamp duty) })_{\mathrm{t}-1}$} & $-0.648 * *$ & $-0.159 * *$ & $-3.559 * *$ & $-0.662 * * *$ \\
\hline & {$[0.257]$} & {$[0.069]$} & [1.819] & {$[0.230]$} \\
\hline $\begin{array}{l}\text { Postcode fixed } \\
\text { effects }\end{array}$ & Yes & Yes & Yes & Yes \\
\hline Year fixed effects & Yes & Yes & Yes & Yes \\
\hline Observations & 21860 & 21860 & 2916 & 2916 \\
\hline Postcodes & 2285 & 2285 & 312 & 312 \\
\hline R-squared & 0.85 & 0.91 & -0.36 & 0.92 \\
\hline Sum of stamp duty & $-0.215^{* *}$ & $-0.265 * * *$ & -0.377 & $-0.633 * * *$ \\
\hline \multirow[t]{2}{*}{ Coefficients } & {$[0.090]$} & {$[0.041]$} & [0.863] & [0.107] \\
\hline & Panel B: & ree-year im & & \\
\hline \multirow[t]{2}{*}{ Log (stamp duty) } & $0 . \overline{679 * *}$ & $-0.194 * * *$ & 1.770 & 0.012 \\
\hline & {$[0.273]$} & [0.071] & [1.126] & {$[0.161]$} \\
\hline \multirow[t]{2}{*}{ Log (stamp duty) $)_{\mathrm{t}-1}$} & $-0.497 * *$ & $0.113^{*}$ & -0.485 & $-0.616 * * *$ \\
\hline & [0.222] & {$[0.064]$} & [0.975] & [0.169] \\
\hline \multirow[t]{2}{*}{ Log (stamp duty) $)_{t-2}$} & $-0.333^{* * *}$ & $-0.292 * * *$ & 2.001 & -0.058 \\
\hline & {$[0.052]$} & [0.039] & [1.255] & [0.183] \\
\hline $\begin{array}{l}\text { Postcode fixed } \\
\text { effects }\end{array}$ & Yes & Yes & Yes & Yes \\
\hline Year fixed effects & Yes & Yes & Yes & Yes \\
\hline Observations & 19209 & 19209 & 2537 & 2537 \\
\hline Postcodes & 2224 & 2224 & 301 & 301 \\
\hline R-squared & 0.88 & 0.91 & 0.35 & 0.922 \\
\hline Sum of stamp duty & $-0.151 *$ & $-0.372 * * *$ & -0.716 & $-0.662 * * *$ \\
\hline Coefficients & {$[0.083]$} & {$[0.045]$} & {$[0.816]$} & [0.137] \\
\hline
\end{tabular}

Note: $* * *, * *$ and $*$ denote statistical significance at the $1 \%, 5 \%$ and $10 \%$ levels, respectively. Standard errors, clustered at the postcode level, in brackets. In the IV specifications, R-squared is the uncentered $\mathrm{R}$-squared in the second-stage regression. In columns 1 and 3 , the log of the actual stamp duty $\left(\ln (\tau)_{\mathrm{t}}\right.$, $\ln (\tau)_{\mathrm{t}-1}$, and $\ln (\tau)_{\mathrm{t}-2}$, where applicable), are instrumented using the stamp duty on an average property in that postcode, assuming prices rose with the national trend $\left(\ln (T)_{\mathrm{t}}, \ln (T)_{\mathrm{t}-1}\right.$, and $\ln (T)_{\mathrm{t}-2}$, where applicable). In columns 2 and 4 , we directly use $\ln (T)_{\mathrm{t}}, \ln (T)_{\mathrm{t}-1}$, and $\ln (T)_{\mathrm{t}-2}$, where applicable, as the stamp duty measures. All specifications are weighted by the number of house sales in that postcodeyear cell.

In Table 5, we look at the effect of lagged stamp duty on housing turnover. In the full sample, the summed coefficients are larger than in the corresponding 1 year 
specification. Instrumenting the stamp duty rate (column 1), the elasticity of turnover with respect to the tax rate rises to -0.47 over 2 years and -0.63 over 3 years. In the reduced form specification (column 2), the elasticity of turnover rises to -0.27 over 2 years and -0.48 over 3 years. This suggests that a 10 per cent increase in stamp duty lowers turnover by 5-6 per cent over the ensuing three years. While the individual coefficients in Table 4 suggest that the impact of stamp duty on house prices is larger in the second and third years; the individual coefficients in Table 5 seem to suggest that the impact of stamp duty on turnover is larger in the first year. A possible explanation is that higher stamp duty rates initially 'throw sand in the gears' of the housing market, and that it takes some time before buyers and sellers agree on a new price equilibrium.

For the subsample of postcodes that are close to state borders (columns 3 and 4), the turnover estimates have large standard errors, and the summed coefficients are never statistically significant. 


\begin{tabular}{|c|c|c|c|c|}
\hline \multicolumn{5}{|c|}{ Table 5: Stamp Duty and House Sales (Medium Run) } \\
\hline & [1] & [2] & {$[3]$} & {$[4]$} \\
\hline & $\begin{array}{l}\text { Full sample } \\
\text { (IV) }\end{array}$ & $\begin{array}{l}\text { Full sample } \\
\text { (reduced } \\
\text { form) }\end{array}$ & $\begin{array}{l}<50 \mathrm{~km} \text { from } \\
\text { border (IV) }\end{array}$ & $\begin{array}{c}<50 \mathrm{~km} \text { from } \\
\text { border } \\
\text { (reduced } \\
\text { form) }\end{array}$ \\
\hline \multicolumn{5}{|c|}{ Panel A: Two-year impacts } \\
\hline \multirow[t]{2}{*}{ Log (stamp duty) } & -0.501 & -0.227 & 21.484 & -0.531 \\
\hline & {$[0.721]$} & [0.117] & [329.235] & {$[0.422]$} \\
\hline \multirow[t]{2}{*}{$\log (\text { stamp duty) })_{\mathrm{t}-1}$} & 0.030 & -0.041 & -25.355 & 0.655 \\
\hline & [0.633] & [0.119] & [396.094] & {$[0.453]$} \\
\hline $\begin{array}{l}\text { Postcode fixed } \\
\text { effects }\end{array}$ & Yes & Yes & Yes & Yes \\
\hline Year fixed effects & Yes & Yes & Yes & Yes \\
\hline Observations & 21860 & 21860 & 2916 & 2916 \\
\hline Postcodes & 2285 & 2285 & 312 & 312 \\
\hline R-squared & 0.07 & 0.14 & -320 & 0.12 \\
\hline Sum of stamp duty & $-0.472 * * *$ & $-0.268 * * *$ & -3.871 & 0.124 \\
\hline Coefficients & {$[0.149]$} & [0.072] & [67.234] & {$[0.232]$} \\
\hline \multicolumn{5}{|c|}{ Panel B: Three-year impacts } \\
\hline \multirow[t]{2}{*}{ Log (stamp duty) } & -0.806 & $-0.465 * * *$ & -38.634 & $-0.868 *$ \\
\hline & {$[0.881]$} & {$[0.121]$} & [1147.619] & {$[0.460]$} \\
\hline \multirow[t]{2}{*}{ Log (stamp duty) $)_{t-1}$} & 0.891 & $0.435 * *$ & 24.205 & 1.343 \\
\hline & [1.093] & {$[0.172]$} & [762.669] & {$[0.679]$} \\
\hline \multirow[t]{2}{*}{ Log (stamp duty) $)_{-2}$} & $-0.720 *$ & $-0.449 * * *$ & 12.506 & -0.572 \\
\hline & [0.389] & [0.139] & [319.067] & [0.479] \\
\hline $\begin{array}{l}\text { Postcode fixed } \\
\text { effects }\end{array}$ & Yes & Yes & Yes & Yes \\
\hline Year fixed effects & Yes & Yes & Yes & Yes \\
\hline Observations & 19209 & 19209 & 2537 & 2537 \\
\hline Postcodes & 2224 & 2224 & 301 & 301 \\
\hline R-squared & -0.33 & 0.13 & -620 & 0.13 \\
\hline Sum of stamp duty & $-0.634 * * *$ & $-0.479 * * *$ & -1.923 & -0.053 \\
\hline Coefficients & {$[0.160]$} & [0.083] & [68.617] & [0.268] \\
\hline
\end{tabular}

Note: $* * *, * *$ and $*$ denote statistical significance at the $1 \%, 5 \%$ and $10 \%$ levels, respectively. Standard errors, clustered at the postcode level, in brackets. In the IV specifications, R-squared is the uncentered R-squared in the second-stage regression. In columns 1 and 3 , the log of the actual stamp duty $(\ln (\tau)$, $\ln (\tau)_{\mathrm{t}-1}$, and $\ln (\tau)_{\mathrm{t}-2}$, where applicable), are instrumented using the stamp duty on an average property in that postcode, assuming prices rose with the national trend $\left(\ln (T)_{\mathrm{t}}, \ln (T)_{\mathrm{t}-1}\right.$, and $\ln (T)_{\mathrm{t}-2}$, where applicable). In columns 2 and 4, we directly use $\ln (T)_{\mathrm{t}} \ln (T)_{\mathrm{t}-1}$, and $\ln (T)_{\mathrm{t}-2}$, where applicable, as the stamp duty measures.

As an additional robustness check, we add statexyear fixed effects into both the firststage and second-stage equations. Since tax policies only vary at the state-year level, the results in this specification are identified only from non-linearities in the tax schedule (it also allows for the possibility that other time-varying state policies are 
correlated with changes in tax rates). With log house prices as the dependent variable, the coefficient on the log stamp duty variable in this specification is -0.066 $(\mathrm{SE}=0.060)$ in the IV specification using all postcodes, and $-0.063(\mathrm{SE}=0.052)$ in the reduced-form specification using all postcodes.

Adding statexyear fixed effects also allows us to create a different instrument, which interacts the starting house price in a postcode with the state-specific price trend. Because this model includes eight times as many fixed effects, the first stage is weaker, with an F-statistic on the excluded instrument of 49, and a partial R-squared of 0.02 (both about one-quarter as large as in the preferred model). With log house prices as the dependent variable, the coefficient on the log stamp duty variable in this specification is -0.161 ( $\mathrm{SE}=0.112$ ) in the IV specification using all postcodes, and a precisely estimated zero in the reduced-form specification using all postcodes. ${ }^{10}$

Another robustness check is to use the stamp duty rate (rather than the log of the stamp duty bill) as the key independent variable. The results from this specification suggest that a one percentage point increase in the stamp duty rate reduces house prices by 6 per cent (with a standard error around 1 per cent). Results are similar in the IV and reduced form specifications. This coefficient is unexpectedly large - an issue to which we return in the final section.

\section{Conclusion}

Using exogenous variation in stamp duty rates, this paper has estimated the impact of changes in stamp duty on house prices and housing turnover. We find statistically significant and economically meaningful impacts of changes in stamp duty on both outcomes. Across all postcodes, the short-term impact of a 10 per cent increase in the stamp duty is to lower house prices by 3 per cent. The effect is larger for homes located near state borders.

Since stamp duty averages only 2-4 per cent of the value of the property, these results imply that the economic incidence of the tax is entirely on the seller; that is, prices fall

$\left.\overline{{ }^{10} \text { Specifically, } 0.0000001(\mathrm{SE}}=0.00000008\right)$. 
by the full amount of the tax. Indeed, the house price results are in some sense 'too large', in that they imply a larger reduction in sale prices than the value of the tax (a New York study by Kopczuk and Munroe 2012 reaches the same conclusion). ${ }^{11}$ Assuming that stamp duty amounts to 4 per cent of the house value, an elasticity of 0 would suggest that the buyer alone bore the tax; an elasticity between 0 and -0.04 would suggest that the stamp duty was shared between the buyer and seller; and an elasticity of - 0.04 would indicate that the seller bore the tax (and thus the net-of-tax sale price would be unaffected by a rise in the stamp duty rate). Elasticities below -0.04 indicate that the seller bears more than the tax (ie. that in dollar terms, the house price drops by more than the size of the increase in the tax bill).

One possible explanation of our 'large' results is that they are partially capturing a compositional effect. Since stamp duty schedules are progressive, they might be expected to have the largest effect on deterring sales of expensive homes. Since we are using postcode average data, this would reduce the mean sale price. We cannot address this question using our data, but hope that future researchers are able to apply our methodology to repeat-sales data to uncover the extent to which compositional bias matters.

We also observe impacts of stamp duty on housing turnover. In the full sample, a 10 per cent increase in stamp duty lowers turnover by 3 per cent in the first year. However, over a 3-year period, a 10 per cent stamp duty increase lowers housing turnover by 6 per cent. Close to state borders, the effects of stamp duty on housing turnover is imprecisely estimated in most specifications.

Taken together, these results imply that stamp duty can have an economically meaningful impact on housing prices and turnover in Australia. Averaging across the five jurisdictions for which we have house price data in all years, the average stamp duty rate on house sales rose from 2.4 per cent in 1993 to 3.3 per cent in 2005 (largely due to 'bracket creep' during a period of rapid house price growth rather than

\footnotetext{
${ }^{11}$ The theoretical model of Lundborg and Skedinger (1999) suggests that the price effect of a housing transaction tax whose legal incidence is on the buyer will be maximised at low vacancy rates, or if the seller has more bargaining power than the buyer.
} 
legislated increases in rates). In percentage terms, this represents a 37 per cent increase in stamp duty over this period - relative to what would have occurred if the rate had remained constant.

To compare our estimates of the impact of stamp duty on housing turnover with the existing literature, we convert our estimates into the effect of a 1 percentage point increase in stamp duty (as a share of the purchase price). Our estimate of a short-run reduction in sales of 8 per cent is the same as Van Ommeren and Leuvensteijn (2005), and lower than Dachis et al (2012) (14 per cent) and Hilber and Lyytikainen (2012) (20 per cent). ${ }^{12}$

In estimating the welfare loss arising from an increase in stamp duty, Dachis et al (2012) show that, where $\tau_{0}$ is the tax bill at the old tax rate, and $\tau$ is the tax bill at the new tax rate, the loss from each forgone transaction is bounded by $\tau_{0}$ below and $\tau_{0}+\tau$ above. ${ }^{13}$ Applying the above tax rates to the average house price in $2005(\$ 345,000)$, we get a welfare loss per foregone sale between $\$ 8000$ and $\$ 20,000$. Since we estimate that the short-run effect of a 10 per cent increase in stamp duty is to reduce sales by 3 per cent, this implies that a 37 per cent increase in stamp duty lowers sales by around 11 per cent. With about 350,000 house sales in 2005, this suggests that the increase in stamp duty rates from 1993 to 2005 led to approximately 39,000 foregone sales. ${ }^{14}$ This puts the annual welfare loss of the stamp duty increase on residential houses at between $\$ 0.3$ billion and $\$ 0.8$ billion.

\footnotetext{
${ }^{12}$ With stamp duty averaging 3.3 per cent of the purchase price in 2005, a 1 percentage point increase in stamp duty equates to a 33 per cent increase in stamp duty. Since we estimate that a 10 per cent increase in stamp duty lowers sales by 2-3 per cent, this suggests that a 1 percentage point (33 per cent) increase in stamp duty would lower sales by around 8 per cent. Estimates for other countries are based upon the figures quoted in section II, but with the estimated effect on turnover divided by the change where necessary (for example, Hilber and Lyytikainen 2012 estimate that a 1.5 percentage point increase led to a 30 per cent reduction in sales, implying a 20 per cent reduction from a 1 percentage point increase)

${ }^{13}$ Intuitively, the lower bound represents the case where every foregone transaction is as costly as the worst transaction that could occur without the stamp duty increase, while the upper bound applies where every foregone transaction is as costly as the best transaction that is foregone as a result of the stamp duty increase.

${ }^{14}$ Our estimate is based on 23 per cent of 350,000. Alternatively, we could base our estimate on a figure that when reduced by 23 per cent came to 350,000 (which would give a slightly larger result).
} 
Note however that this estimate only encompasses internal costs, omitting potential negative and positive externalities from reducing housing mobility. Impeding housing mobility may cause individuals to forego better job offers in other regions (thereby reducing productivity of co-workers), or to commute overly long distances to a new job (thereby increasing road congestion) (van Ommeren 2008). Housing transaction taxes may lead to misallocation of the housing stock, by effectively discouraging young families to upsize their housing and by discouraging retiree households from downsizing (see Glaeser and Luttmer 2003). Conversely, if residential turnover reduces the social capital in a neighbourhood (see for example Dietz and Haurin 2003; Frijters and Leigh 2008), then higher stamp duties may internalise the negative externality that movers impose on their postcode.

Moreover, it is important to compare our estimated welfare costs with those from other taxes, since governments raising stamp duties are likely to be doing so in a bid to meet a given revenue target. While recurrent land or property taxes are potentially a more efficient way of raising revenue, land transfer taxes may be an appropriate second-best policy where recurrent land taxes are infeasible. 


\section{References}

Australian Bureau of Statistics (1995), Taxation Revenue, Australia, 1994-95, Cat No 5506.0, ABS, Canberra.

Australian Bureau of Statistics (2012a), Building Activity Australia, Cat No 8572.0, ABS, Canberra.

Australian Bureau of Statistics (2012b), Taxation Revenue, Australia, 2010-11, Cat No 5506.0, ABS, Canberra.

Australian Government. (2010), Australia's future tax system: final report, Australian Government, Canberra.

Benjamin, J.D., Coulson, N.E. and Yang S.X. (1993), 'Real Estate Transfer Taxes and Property Values: The Philadelphia Story', Journal of Real Estate Finance and Economics, 7, 151-157.

Bertrand, M., Duflo, E. and Mullainathan, S. (2004), 'How Much Should We Trust Differences-in-Differences Estimates?', Quarterly Journal of Economics, 119, 249275

Brueckner, J. (1997), 'Infrastructure financing and urban development: the economics of impact fees’; Journal of Public Economics, 66 383-407.

Dachis, B., Duranton, G and Turner, M.A (2012), 'The effects of land transfer taxes on real estate markets: Evidence from a natural experiment in Toronto", Journal of Economic Geography, 12, 327-354.

Dietz, R.D. and Haurin, D.R. (2003), 'The Social and Private Micro-Level Consequences of Homeownership', Journal of Urban Economics, 54, 401-450.

The Economist, (2011) 'House-Price Indicators'. Available from:

http://www.economist.com/blogs/dailychart/2011/11/global-house-prices.

Ellis, E. (2006), Housing and Housing Finance: The View from Australia and Beyond', Reserve Bank of Australia Research Discussion Paper 2006-12, RBA, Sydney.

Feldstein, M. and Wrobel, M.V. (1998), 'Can State Taxes Redistribute Income?' Journal of Public Economics 68, 369-96.

Frijters, P. and Leigh, A. (2008), 'Materialism on the March: From Conspicuous Leisure to Conspicuous Consumption?’ Journal of Socio-Economics, 37, 1937-1945

Glaeser, E. and Luttmer, E.F.P. (2003), 'The Misallocation of Housing Under Rent Control’, American Economic Review, 93, 1027-1046. 
Hatzvi, E. and Otto, G. (2008), 'Prices, Rents and Rational Speculative Bubbles in the Sydney Housing Market’ Economic Record, 84, 405-420.

Hilber, C.A.L. and Lyytikainen, T. (2012), 'Stamp duty and household mobility: Regression discontinuity evidence from the UK', Spatial Economics Research Centre Discussion Paper 115, London School of Economics, London.

Huffman, E. et al. (1988),'Who Bears the Burden of Development Impact Fees?' Journal of the American Planning Association, 54, 49-55.

Ihlanfeldt, K. and Shaughnessy, T. (2004). 'An empirical investigation of the effects of impacts on housing an land markets,' Regional Science and Urban Economics, 34, 639-661.

International Monetary Fund (2012), Australia: Staff Report for the 2012 Article IV Consultation. International Monetary Fund, Washington, DC.

Kopczuk, W. and Munroe, D. (2012). 'Mansion Tax: The Effect of Transfer Taxes on residential Real Estate Market' Working Paper, Available from: http://bepp.wharton.upenn.edu/bepp/assets?File/AE-F12-Kop

Leigh, A. (2008), 'Do Redistributive State Taxes Reduce Inequality?' National Tax Journal, 61, 81-104

Lundborg, P. and Skedinger, P. (1999), 'Transaction taxes in a search model of the housing market’ Journal of Urban Economics, 45, 385-399.

National Housing Supply Council (2011). 'State of Supply Report', Australian Government. Canberra.

Oates, W. (1969), 'The effects of property taxes and local public spending on property values: an empirical study of tax capitalization and the Tiebout hypothesis', Journal of Political Economy, 77, 957-971.

O'Sullivan, A., Sedon, T. and Sheffin, S. (1995), 'Property taxes, mobility and homeownership', Journal of Urban Economics, 37, 107-129.

Palmon, O. and Smith, B. (1998), 'New Evidence on Property Tax Capitalization', Journal of Political Economy, 106, 1099-111.

Schaffer, M.E., (2007), xtivreg2: Stata module to perform extended IV/2SLS, GMM and AC/HAC, LIML and k-class regression for panel data models. Available from: http://ideas.repec.org/c/boc/bocode/s456501.html

Staiger, D. and Stock, J.H. (1997) 'Instrumental Variables Regression with Weak Instruments,' Econometrica, 65, 557-586.

van Ommeren, J. (2008), 'Transaction Costs in Housing Markets', Tinbergen Institute Discussion Paper TI2008-099/3. Tinbergen Institute, Amsterdam. 
van Ommeren, J. and van Leuvensteijn, M. (2005), 'New evidence of the effect of transaction costs on residential mobility’, Journal of Regional Science, 45, 681-702.

Yates, J. (2011) 'Housing in Australia in the 2000s: On the Agenda Too Late?' in The Australian Economy in the 2000s, Reserve Bank of Australia, Sydney, 261-296.

Yates, J. and Whelan, S. (2009) Housing Wealth and Consumer Spending, AHURI Final Report No 132, Australian Housing and Urban Research Institute, Melbourne.

Zodrow, G. (2001). 'The Property Tax as a Capital Tax: A Room With Three Views', National Tax Journal, 54, 139-156. 
Table A1: Stamp Duty and House Prices, Instrumented Using Price Ratio Over the Full Period

Dependent variable is the mean log house price

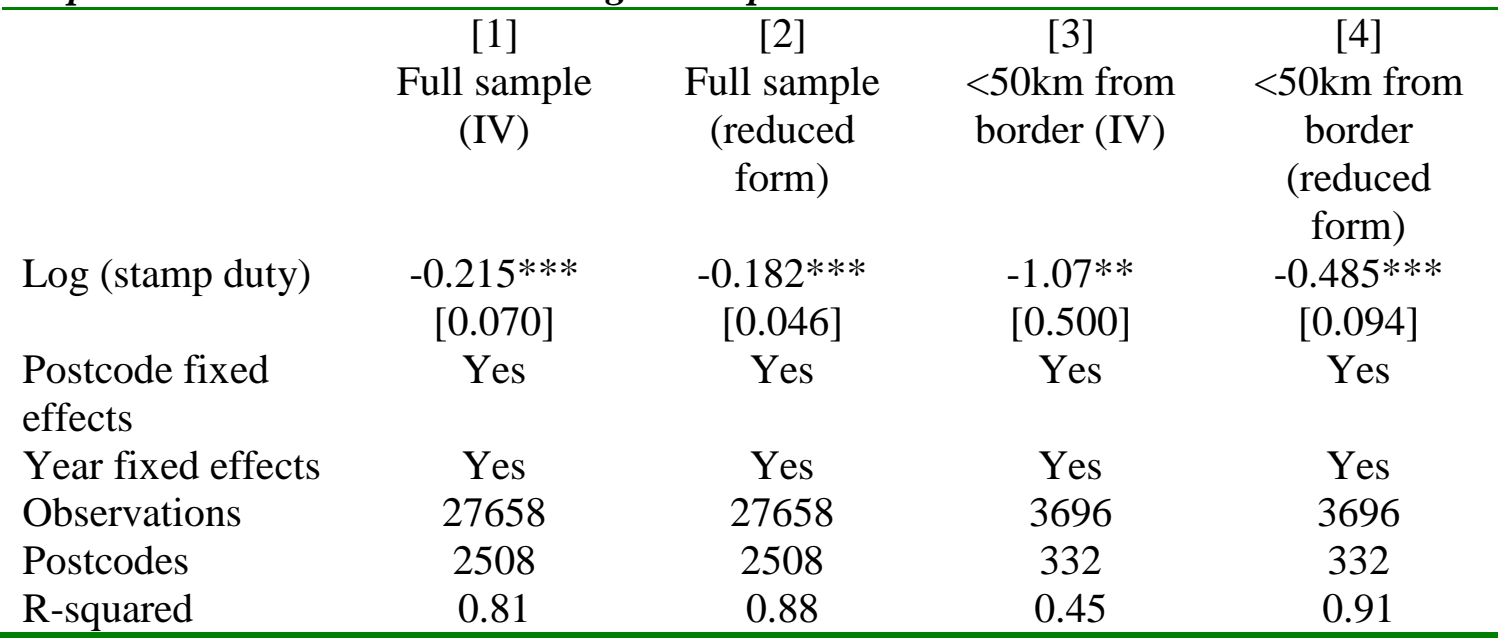

Note: $* * *, * *$ and $*$ denote statistical significance at the $1 \%, 5 \%$ and $10 \%$ levels, respectively. Standard errors, clustered at the postcode level, in brackets. In the IV specifications, R-squared is the uncentered R-squared in the second-stage regression. In columns 1 and 3, the log of the actual stamp duty $(\ln (\tau))$, is instrumented using the stamp duty on an average property in that postcode, assuming that prices in that postcode took the same ratio across the sample period, and rose with the national trend $(\ln (T))$. For example, if sales data are available for 19932005, the instrumented stamp duty amount in 2002 is equal to the national price in 2002, multiplied by the average price in that postcode for the period 1993-2005, divided by the average national price for the period 1993-2005. In columns 2 and 4, we directly use $\ln (T)$ as the stamp duty measure. All specifications are weighted by the number of house sales in that postcode-year cell.

Table A2: Stamp Duty and House Sales, Instrumented Using Price Ratio Over the Full Period Dependent variable is the log of the number of house sales

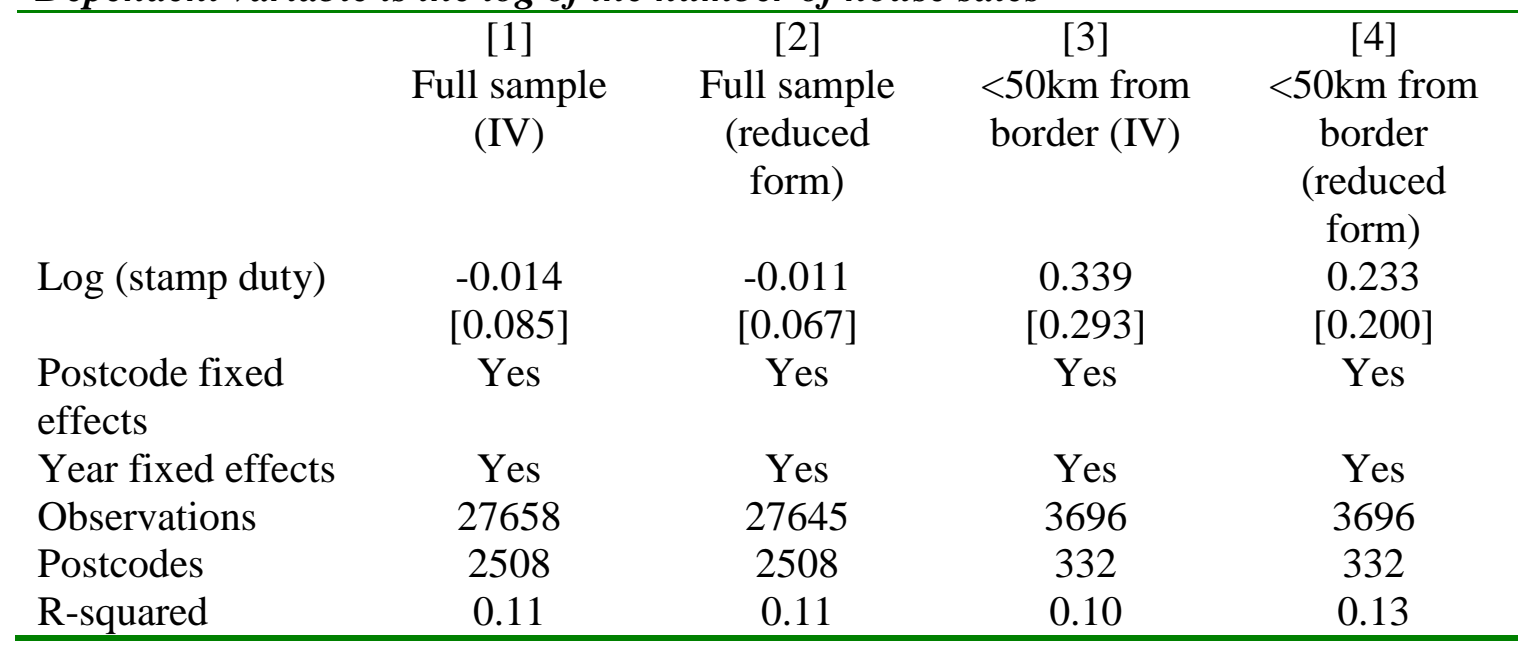

Note: $* * *, * *$ and $*$ denote statistical significance at the $1 \%, 5 \%$ and $10 \%$ levels, respectively. Standard errors, clustered at the postcode level, in brackets. In the IV specifications, R-squared is the uncentered R-squared in the second-stage regression. In columns 1 and 3 , the log of the actual stamp duty $(\ln (\tau))$, is instrumented using the stamp duty on an average property in that postcode, assuming that prices in that postcode took the same ratio across the sample period, and rose with the national trend $(\ln (T)$ ). For example, if sales data are available for 19932005, the instrumented stamp duty amount in 2002 is equal to the national price in 2002, multiplied by the average price in that postcode for the period 1993-2005, divided by the average national price for the period 1993-2005. In columns 2 and 4, we directly use $\ln (T)$ as the stamp duty measure. 
Table A3: Stamp Duty and House Prices, Instrumented Using Price Ratio in Starting Year

Dependent variable is the mean log house price

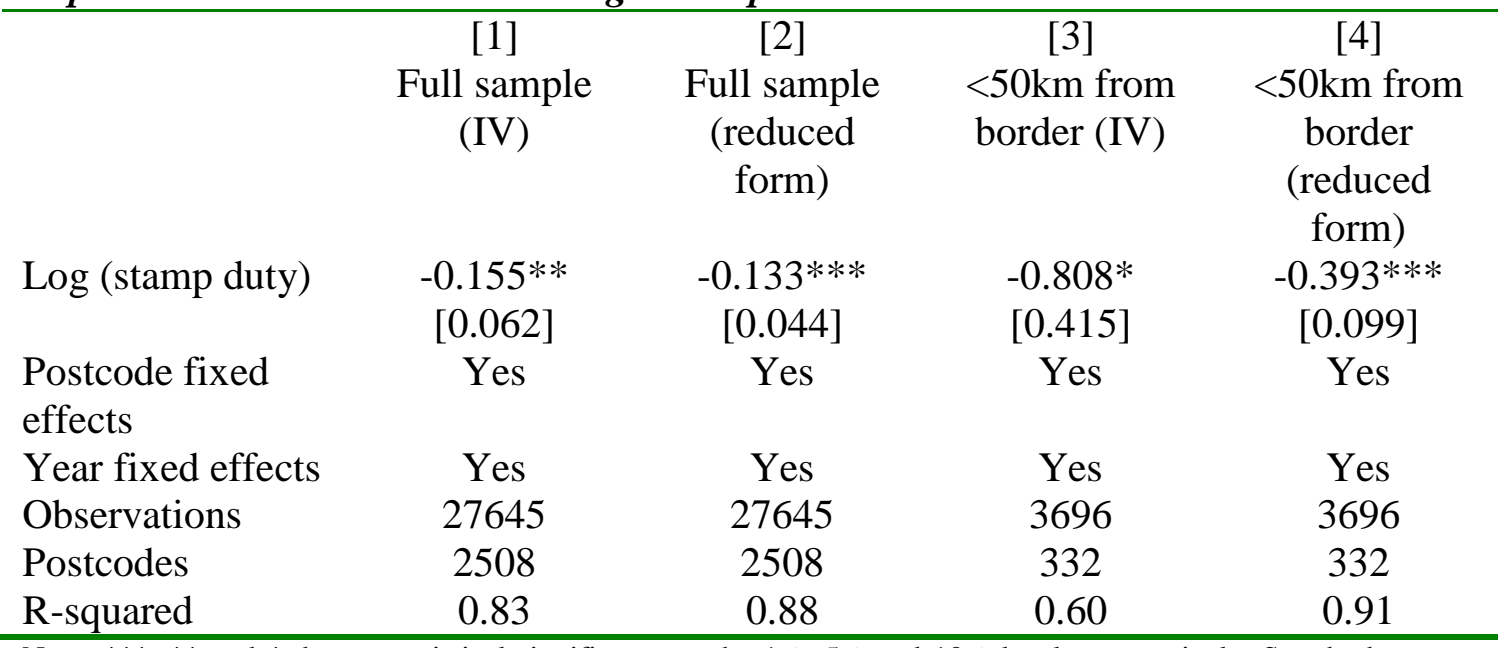

Note: $* * *, * *$ and $*$ denote statistical significance at the $1 \%, 5 \%$ and $10 \%$ levels, respectively. Standard errors, clustered at the postcode level, in brackets. In the IV specifications, R-squared is the uncentered R-squared in the second-stage regression. In columns 1 and 3, the log of the actual stamp duty $(\ln (\tau))$, is instrumented using the stamp duty on an average property in that postcode, assuming that prices in that postcode took the same ratio in the starting year, and rose with the national trend $(\ln (T))$. For example, if sales data are available for 1993-2005, the instrumented stamp duty amount in 2002 is equal to the national price in 2002, multiplied by the average price in that postcode in 1993, divided by the average national price in 1993. In this specification, we do not drop the 1993 observation. In columns 2 and 4, we directly use $\ln (T)$ as the stamp duty measure. All specifications are weighted by the number of house sales in that postcode-year cell.

\begin{tabular}{|c|c|c|c|c|}
\hline \multicolumn{5}{|c|}{$\begin{array}{l}\text { Table A4: Stamp Duty and House Sales, Instrumented Using } \\
\text { Starting Year } \\
\text { Dependent variable is the log of the number of house sales }\end{array}$} \\
\hline \multirow{4}{*}{ Log (stamp duty) } & [1] & {$[2]$} & [3] & {$[4]$} \\
\hline & $\begin{array}{l}\text { Full sample } \\
\text { (IV) }\end{array}$ & $\begin{array}{l}\text { Full sample } \\
\text { (reduced } \\
\text { form) }\end{array}$ & $\begin{array}{l}<50 \mathrm{~km} \text { from } \\
\text { border (IV) }\end{array}$ & $\begin{array}{l}<50 \mathrm{~km} \text { from } \\
\text { border } \\
\text { (reduced } \\
\text { form) }\end{array}$ \\
\hline & $-0.208 *$ & $-0.120 *$ & -0.269 & -0.074 \\
\hline & [0.122] & [0.069] & {$[0.731]$} & [0.195] \\
\hline $\begin{array}{l}\text { Postcode fixed } \\
\text { effects }\end{array}$ & Yes & Yes & Yes & Yes \\
\hline Year fixed effects & Yes & Yes & Yes & Yes \\
\hline Observations & 27645 & 27645 & 3696 & 3696 \\
\hline Postcodes & 2508 & 2508 & 332 & 332 \\
\hline R-squared & 0.10 & 0.11 & 0.10 & 0.13 \\
\hline
\end{tabular}

Note: $* * *, * *$ and $*$ denote statistical significance at the $1 \%, 5 \%$ and $10 \%$ levels, respectively. Standard errors, clustered at the postcode level, in brackets. In the IV specifications, R-squared is the uncentered R-squared in the second-stage regression. In columns 1 and 3, the log of the actual stamp duty $(\ln (\tau))$, is instrumented using the stamp duty on an average property in that postcode, assuming that prices in that postcode took the same ratio in the starting year, and rose with the national trend $(\ln (T))$. For example, if sales data are available for 1993-2005, the instrumented stamp duty amount in 2002 is equal to the national price in 2002, multiplied by the average price in that postcode in 1993, divided by the average national price in 1993. In this specification, we do not drop the 1993 observation. In columns 2 and 4, we directly use $\ln (T)$ as the stamp duty measure. 